\title{
Bladder Benign PEComa
}

National Cancer Institute

\section{Source}

National Cancer Institute. Bladder Benign PEComa. NCI Thesaurus. Code C159674.

A benign perivascular epithelioid cell tumor arising from the bladder. 